\title{
Penerapan Gaya Kepemimpinan Transformasional terhadap Pemberdayaan Sumber Daya Manusia pada PT Citra Karya Persada Cilacap
}

\author{
Hari Sucahyowati ${ }^{1}$, Andi Hendrawan ${ }^{2}$ \\ ${ }^{1,2}$ AkademiMaritim Nusantara, Cilacap \\ harisucahyowati@amn.ac.id
}

Diterima 02 September 2021, direvisi 11 September 2021, diterbitkan 06 Oktober 2021

\begin{abstract}
Abstrak
Banyak model teori kepemimimpinan, salah satunya adalah model kepemimpinan transformasional.Bagaimana penerapan model kepemimpinan ini diterapkan dalam dunia usaha pada umumnya, terutama di PT. Citra Karya Persada yang merupakan perusahaan jasa penyedia tenaga kerja, akan menjadi diskusi yang menarik karena perusahaan jasa ini banyak melibatkan sumber daya manusia. Artikel ini hendak mengulas tentang konsep kepemimpinan transformasional yaitugaya kepemipinan yang bisa mengganti visi dan misi menjadi aksi, mentransformasikan orang supaya ingin berganti ke arah kenaikan mutu diri. Penerapannya terdapat sebagian aspek yang mempengaruhinya yaitu pengaruh ideal, motivasi inspirasional, pertimbangan individu, dan stimulasi intelektual. Metode penyusunan artikel ini menggunakan metode observasi atau pengamatan langsung dan juga metode studi pustaka. Tujuan penyusunan artikel ini untuk menggambarkan secara komprehenshif tentang konsep kepemimpinan, model kepemimpinan transformasional, serta ciri kepemimpinan transformasional terhadap pemberdayaan sumber daya manusia di PT. Citra Karya Persada Cilacap.
\end{abstract}

Kata Kunci : Gaya Kepemimpinan Transformasional, Pemberdayaan Karyawan

\begin{abstract}
There are many models of leadership theory, one of which is the transformational leadership model. How the application of this leadership model is applied in the business world in general, especially in PT. Citra Karya Persada which is a labor provider service company, will be an interesting discussion because this service company involves a lot of human resources. This article wants to discuss the concept of transformational leadership, namely leadership that can change vision and mission into action, transforming people to want to change towards improving self-quality. Its application has several aspects that influence it, namely ideal influence, inspirational motivation, individual considerations, and intellectual stimulation. This method of preparing this article uses observation or direct observation methods and also library study methods. The purpose of the preparation of this article is to comprehensively describe the concept of leadership, transformational leadership model, and transformational leadership characteristics towards human resource empowerment in PT. Persada Cilacap.
\end{abstract}

Keywords: Transformational Leadership Style, Employee Empowerment

\section{Pendahuluan}

Lingkungan bisnis telah berubah secara spektakuler dalam dekade terakhir. Liberalisasi, perdagangan, deregulasi dan promosi teknologi Informasi menciptakan persaingan yang ketat sebagai buah Globalisasi. Persaingan yang ketat ini "memaksa" organisasi-organisasi untuk membuat kreativitas, pengurangan tenaga kerja, dan restrukturisasi.

Menghadapi perubahan ini, kebutuhan pemimpin untuk membuat perubahan radikal bagaimana mengelola sumber daya manusia dan organisasi. [1] Dengan jumlah karyawan yang lebih ramping dituntut untuk menangani lebih 
banyak beban kerja, pemimpin harus terusmenerus mencoba dan kreatif untuk mengembangkan kapasitas semua sumber daya yang dimiliki organisasi, agar mampu mengikuti berbagai perubahan untuk menghadapi persaingan industri dalam perubahan yang berlangsung cepat.

Menghadapi perubahan lingkungan yang terus berlanjut, dan memobilisasi aset penting dari perusahaan 3/4 sumber daya manusia dibutuhkan konsep kepemimpinan baru. pemimpin perlu memiliki kemampuan dalam mengembangkan sumber daya manusia yang berkelanjutan sampai mereka mencapai tingkat potensi mereka, kalu perlu mencapai tingkat yang jauh lebih baik.

Isu kepemimpinan selalu menjadi bahan diskusi yang menarik, karena kepemimpinan menjadi salah satu faktor yang penting dalam organisasi dalam mencapai tujuannya, begitu juga issue kepemimpinan di dunia pendidikan. Itu telah dibuktikan dalam berbagai penelitian bahwa keberhasilan pengembangan organisasi ditentukan oleh karakter pemimpinnya. Sebagaimana penelitian yang dilakukan Covey yang dikutip oleh Muhaimin et, al, bahwa sebagian besar kegagalan kepemimpinan disebabkan kegagalan karakter. [2] Kualitas kepemimpinan akan berpengaruh besar terhadap keberhasilan organisasi, pemimpin yang berkualitas kinerja organisasi akan meningkat pengetahuan, kompetensi dan motivasi kerja anggotanya juga akan meningkat yang akhirnya akan meningkatkan kepuasan kerja anggota.

Kepemimpinan sanggup mempengaruhi para anggota untuk mengubah perilaku, bergerak sesuai dengan kemauan pemimpinnya, sebab kepemimpinan menjadi kekuatan aspirasional, kekuatan semangat, serta kekuatan moral yang kreatif untuk, hingga gaya seseorang di dalam memimpin sangat mewarnai organisasi yang dipimpinnya.

Banyak model teori kepemimimpinan, salah satunya adalah model kepemimpinan transformasional. Bagaimana penerapan model kepemimpinan transformasional ini diterapkan dalam dunia usaha pada umumnya, terutama di PT Citra Karya Persada yang merupakan perusahaan jasa penyedia tenaga kerja, akan menjadi diskusi yang menarik karena perusahaan jasa ini banyak melibatkan sumber daya manusia.
Ada banyak definisi tentang kepemimpinan, tetapi pada umumnya sepakat bahwa kepemimpinan adalah sebuah proses mempengaruhi orang lain, sehingga orang lain tersebut dengan kesadarannya bersedia menjalankan proses sesuai dengan kehendak pemimpinnya. Menurut Prajudi Atmosudirjo kepemimpinan dapat didefinisikan: [3]

1. Kepemimpinan bisa diformulasikan sebagai sesuatu karakter (personality) seorang yang mendatangkan suatu kemauan yang ditujukan kepada seseorang ataupun sekelompok orang untuk mengikutinnya, ataupun memancarkan sesuatu pengaruh kepada anggotannya. Apabila dibawakan dalam dunia pendidikan merupakan suatu wujud keiginan berbentuk perintah yang membuat seseorang melaksanakannnya.

2. Kepemimpinan bisa dilihat sebagai pemicu kegiatan, proses, ataupun kesediaan buat mengubah suatu pemikiran, ataupun perilaku pada sekelompok orang. bila dibawakan dalam dunia pendidikn seseorang pemimpin sanggup merubah serta pengaruhi perilaku bawahan ataupun anggotanya dengan gaya kepemimpinan yang dimilikinnya.

3. Kepemimpinan dimaksud selaku suatu seni (art), kesanngupan (ability), ataupun teknik untuk membuat anggota ataupun bawahan bergairah mematuhinnya dan dengan sukarela berkorban untuknya

4. Kepemipinan merupakan sesuatu yang dipandang sebagai suatu seni pembinaan kepada sesuatu anggota kelompok, umumnya lewat human relations serta motivasi yang pas tanpa rasa khawatir serta diancam, sekelompok orang itu sanggup melaksanakannya, karena adanya faktor ajakan serta motivasi dari seorang yang mempunyai pengaruh besar dalam anggota ataupun kelompok itu.

\section{Materi dan Metode}

Salah satu faktor yang terus mempengaruhi efektivitas kepemimpinan dalam setidaknya sepuluh tahun mendatang adalah hubungan antara pemimpin dan mampu tutwuri. Inti dari reaksi adalah hubungan interaksi yang ditolak dalam motivasi dan kekuatan potensial, termasuk keterampilan, untuk mencapai tujuan bersama. 
Ada dua bentuk interaksi, yaitu fitorifikasi dan kepemimpinan transformasional. [4]

Pertukaran informasi antar individu antara manajer dan karyawan yang dalam komunikasi yang harmonis menjadi fokus model kepemimpinan transformasional

Komunikasi didasarkan pada kesesuaianantara tugas yang harus dijalankan dan memberikan penghargaan atas pencapaian tugas (realisasi). Ada dua fitur utama dari jenis ini:

1. Manajer memberikan penghargaan berupa serangkaian hadiah kepada karyawan untuk memberi motivasi;

2. Manajer tidak akan melakukan koreksi ketika bawahannya gagal mencapai tujuan institusi. Dengan demikian, kepemimpinan transaksional mengarah pada upaya keinginan atau memelihara status quo.

Sementara dengan kepemimpinan transformasional, atau sering disebut kepemimpinan karismatik, para pemimpin menciptakan visi dan lingkungan yang mendorong karyawan untuk mencapai harapan. Dalam hal ini, karyawan memiliki kepercayaan, dan menghormati pemimpin mereka sehingga termotivasi untuk melakukan lebih banyak apa yang menjadi harapan mereka. Bahkan tidak jarang mereka dapat bekerja melebihi apa yang mereka untuk mencapi harapan mereka. Model kepemimpinan yang lebih cepat selama dua dekade terakhir tergantung pada upaya para pemimpin untuk mengubah nilai yang berbeda. Kepercayaan diri dan kebutuhan bawahan.

Kepemimpinan transformasional ialah kepemimpinan yang berusaha membawa perubahan organisasi (selaku lawan manajemen yang mempertahankan status quo). Gaya kepemimpinan ini hendak membawa superioritas dalam organisasi yang menolak pembaharuan. Seseorang pemimpin bisa mengganti bawahannya dengan 4 saluran yang dikenal 4 I[1], yaitu:

1. Pengaruh ideal para pemimpin transformasional memberikan contoh dan bentuk pola perilaku, sikap dan komitmen terhadap bawahannya. Dia sangat perhatian dengan kebutuhan bawahannya, membawa risiko bersama, tidak menggunakan kekuatannya untuk keuntungan pribadi, memberikan visi dan misi, menanamkan perasaan bangga pada bawahannya. Berkat pengaruh ini, bawahan akan menghormati, takjub, dan percaya pada para pemimpin mereka, mereka ingin menduplikasi pemimpinnya. Ini tentu sangat berguna dalam hal adaptasi terhadap perubahan, terutama apabila oragniasi melakukan perubahan yang radikal dan fundamental.

2. Motivasi inspirasional. Pemimpin transformasional harus mampu meberi memotivasi dan menjadi inspirasi karyawannya dengan mengkomunikasikan apa yang menjadi harapan pemimpin terutama harapan-harpan yang tinggi, menggunakan berbagai simbol untuk memfokuskan upaya atau tindakan, dan mengekspresikan tujuan yang signifikan dengan cara yang sederhana.

3. Stimulasi intelektual. Para pemimpin transformasional berusaha menciptakan iklim yang sejuk dan sehat untuk pengembangan inovasi dan kreativitas. Para pemimpin mendorong bawahan untuk menempatkan solusi baru dan kreatif untuk masalah yang dihadapi. Karena bawahannya terlibat dalam proses merumuskan masalah dan pencarian solusi.

4. Ujian individual. Para pemimpin transformasional memberikan atensi khusus pada kebutuhan karayawan untuk berkembang dan mencapai harapan, dengan bertindak sebagai pelatih atau penasihat (mentor) kalau perlu menjadi sahabat. Melalui interaksi pribadi, hubungan pemimpin dan karyawan dapat meningkat.

Pemimpin yang transformasional setidaknya memiliki empat sifat, yaitu [5]

1. Kharisma: bisa membuat visi dan misi, tantangan dan rasa bangga, hormat menghormati dan kepercayaan/trust.

2. Inspiratif: Mengkomunikasikan harapan yang baik, menggunakan berbagai simbol upaya menyampaikan harapan menjadi fokus, dan dengan cara sederhana dan mudah dipahami dalam mengekspresikan tujuan. 
3. Stimulasi Intelektual Mempromosikan kecerdasan, rasionalitas, dan pemecahan masalah dengan hati-hati.

4. Pertimbangan yang bersifat individual: memberikan perhatian khusus, perlakukan karyawan secara individu, berlatih, konselor.

Tabel [5]

Karakteristik Pemimpin Transformasional

\begin{tabular}{|c|c|c|}
\hline Model Tichy \& Devanna & Model Kouzes \& Posner & Model Bass \\
\hline $\begin{array}{l}\text { - Identifikasi kebutuhan } \\
\text { revitalisasi }\end{array}$ & $\begin{array}{l}\text { - Mempertanyakan } \\
\text { proses yang ada }\end{array}$ & \\
\hline $\begin{array}{l}\text { - Pembentukan visi baru dan } \\
\text { mobilisasi komitmen }\end{array}$ & $\begin{array}{l}\text { - Menginspirasikan visi } \\
\text { bersama (shared vision) } \\
\text { - Memungkinkan orang } \\
\text { lain untuk bertindak }\end{array}$ & $\begin{array}{l}\text { - Kharisma } \\
\text { - Inspirasi }\end{array}$ \\
\hline $\begin{array}{l}\text { - Pelembagaan } \\
\text { - Perubahan }\end{array}$ & $\begin{array}{l}\text { - Menciptakan model } \\
\text { - Mendorong semangat } \\
\text { bawahan }\end{array}$ & $\begin{array}{l}\text { - Stimulasi intelektual } \\
\text { - Konsiderasi yang } \\
\text { bersifat individual }\end{array}$ \\
\hline
\end{tabular}

Metode penyusunan artikel ini menggunakan metode observasi atau pengamatan langsung dan juga metode studi pustaka

\section{Hasil dan Pembahasan}

Inti dari kepemimpinan transformasional adalah pendelegasian wewenang yang melibatkan karyawan untuk secara bersama berubah untuk mencapai tujuan organisasi. Dengan menjalankan model ini pimpinan PT. Cipta Karya Persada mampu menguatkan kepercayaan diri karyawan akan kemampuan dirinya untuk meningkatkan kemampuan diri (sense of self-efficacy) yang lebih kuat untuk menyelesaikan berbagai tantangan dalam pekerjaan mereka sehari-hari.

Saat ini, konsep pemberdayaan telah diterapkan pimpinan PT. Citra Karya Persada sebagai salah satu pandangan baru untuk meningkatkan motivasi dan produktivitas karyawan. Berkat konsep ini, karyawan dipercayakan dengan otoritas dan tanggung jawab yang lebih besar dalam pengambilan keputusan. Pimpinan PT. Citra Karya Persada juga telah melakukan komunikasi atau pertukaran informasi dan pengetahuan antara manajer dan karyawan sehingga karyawan dapat benar-benar mengerti tugas mereka dan dapat memberikan kontribusi nyata terhadap pencapaian keberhasilan organisasi. Pemberdayaan berbeda dari partisipasi yang berbeda dari pendekatan di masa lalu, yang cenderung menekankan entri/pengumpulan karyawan, tetapi tidak menggunakannya dan/atau tidak dibarengi dengan pendelegasian wewenang.

Aspek sebenarnya dari pemberdayaan bukanlah hal mutlak, tetapi lebih merupakan masalah jenjang jabatan, artinya, tingkat pemberdayaan masing-masing individu dan tim tidak harus menjadi bagian yang sama atau pada tingkat yang sama. Bahkan untuk beberapa tugas individu atau tanggung jawab kelompok kerja tertentu di zona keputusan (bidang keputusan) yang dapat diterapkan pada berbagai tingkat pemberdayaan. Pemilihan strategi pemberdayaan yang diterapkan oleh Pimpinan PT. Citra Karya Persada dilakukan dengan memeriksa dua dimensi, yaitu konten pekerjaan dan konteks pekerjaan. Konten pekerjaan menggambarkan tugas dan prosedur yang diperlukan untuk melakukan pekerjaan tertentu. Meskipun konteks pekerjaan menggambarkan kecukupan bekerja dengan misi yang ditargetkan, tujuan organisasi dan parameter organisasi di mana pekerjaan tersebut dilaksanakan. Setidaknya ada 5 (lima) strategi pemberdayaan karyawan yang digunakan oleh pimpinan PT. Citra Karya Persada berdasarkan lima ukuran ini, yaitu:

1. Tidak ada kebijaksanaan (No Discretion) menjelaskan tugas yang sangat rutin dan berulang-ulang. Karyawan tidak berpartisipasi dalam desain pekerjaan. Tindak lanjut diberikan kepada orang lain. Dengan demikian, tidak ada otoritas pengambilan keputusan yang berkaitan dengan isi pekerjaan dan konteks pekerjaan

2. Tugas pengaturan (Task Setting), yaitu karyawan merasa memiliki tanggung jawab penuh melakukanpekerjaannya dan diberikan kewenangan untuk menentukan kebijakan dalam konteks dan lingkup pekerjaanya. Dalam hal ini, manajemen misi dan tujuan, sementara karyawan berhak untuk mencari cara terbaik untuk sampai ke sana.

3. Pemberdayaan partisipatif (Participatory Empowerment), dimana karyawan berpartisipasi aktif dalam mengambil keputusan tentang konten pekerjaan dan konteks pekerjaan mereka terutama dalam melakukan identifikasi masalah, pengembangan alternatif, dan rekomendasi lainnya dalam pekerjaan. Mereka juga 
terlibat untuk kegiatan yang sama dalam pengambilan keputusan untuk konteks kerja.

4. Mendefinisikan misi (Mission Definition), dimana karyawan berhak untuk memutuskan apa yang sebaiknya dilakukan dalam konteks kerja.

5. Manajemen diri (Self-Management), untuk memberikan kekuasaan penuh kepada karyawan untuk membuat keputusan mengenai isi dari kerja dan kerangka kerja, kepercayaan pada kemampuan karyawan untuk pemberdayaan digunakan untuk meningkatkan efektivitas organisasi. Di sisi lain, partisipasi yang tinggi juga diperlukan dari karyawan dalamikut serta mengembangan misi dan tujuan organisasi.

\section{Kesimpulan}

Pimpinan PT. Citra Karya Persada memilih menggunakan pendekatan yang lebih relevan yaitu model kepemimpinan transformasional. Berkat konsep ini dan dikombinasikan dengan dimensi pemberdayaan, karyawan dipercayakan dengan otoritas dan tanggung jawab yang lebih besar dalam pengambilan keputusan. Karyawan PT. Citra Karya Persada telah memberikan kontribusi nyata terhadap pencapaian tujuan perusahaan, karena pemimpinnya melakukan komunikasi atau pertukaran informasi dan pengetahuan antara manajer dan karyawan.

\section{Ucapan Terima Kasih}

Terimakasih Penulis ucapkan kepada Akademi Maritim Nusantara yang telah memberikan fasilitas berupa dukungan moril dan materiil sehingga penulisan artikel ini bisa terlaksana, tidak lupa juga mengucapkan terimakasih atas kesediaan PT. Citra Karya Persada yang telah mengijinkan penulis untuk mengamati dan melakukan wawancara untuk dijadikan bahan penulisan artikel ini.

\section{Daftar Pustaka}

[1] B. M. \& B. J. A. Bass, Improving Organizational Effectiveness Through Transformational Leadership. Thousand Oaks: SAGE Publications, Inc., 1994.

[2] E. Al Muhaimin, Manajemen Pendidikan,Aplikasinya dalam Penyusunan Rencana Pengembangan Sekolah Madrasah. Jakarta: Kencana Prenada Media Group, 2010.

[3] A. Prajudi, Administrasi dan Manajemen Umum. Jakarta: Ghalia Indonesia., 2006.

[4] J. H. Gibson, J.L., Ivancevich, J.M., \& Donnelly, Jr., Organizations: Behavior, Structure, Processes., III. Homewood: Richard D. Invin, Inc., 1991.

[5] Hani Handoko; Fandy Tjiptono, "Kepemimpinan Transformasional Dan Pemberdayaan," J. Ekon. dan Bisnis Indones., vol. 11 No 1, 1996. 